\section{The effect of hippocampectomy and prior experience in exploratory activity in the albino rat $^{1}$}

\author{
JEROME S. COHEN, University of \\ Windsor, Windsor 11, Ont., Canada, and \\ LEELAND C. SWENSON, ${ }^{2}$ Wayne State \\ University, Detroit, Mich. 48202
}

Exposure to a novel alley (E-alley) did not affect exploration of this alley during straight running for reinforcement in later trials for hippocampectomized (HIP) rats. Unoperated (NORM) and neocortical-lesioned (CORT) $S$ s explored E-alley more than did HIP Ss. Side of final presentation of E-alley affected only NORM Ss, the E-alley presented on the same side as during the initial exposure eliciting more entries. The lack of perseverative entries to the same-sided E-alley in HIP Ss is contrary to predictions based on Douglas's (1967) model of hippocampal functioning.

Douglas (1967) maintains that the hippocampus acts as a stimulus-gating mechanism to allow behavior flexibility by decreasing stimulus bonds no longer needed by $S$. Hippocampectomy in rats removes this stimulus-gating mechanism and $S$ will continue to respond to the first stimulus it responded to even though the situation demands different responses. Thus, Douglas has interpreted perseverative responses seen in activity cages or open-field situations (Kimble, 1963; Sengstake, 1968), lack of alternation behavior in T-maze (Leaton, 1965), and poor maze learning due to perseverative errors (Hostetter \& Thomas, 1967) by hippocampectomized rats as lack of habituation to novel stimuli. Recent work (Cohen, 1969) has found that hippocampectomized rats explore a side or E-alley less than do normal and neocortical control Ss. The perseverative straight running of the hippocampectomized Ss might be due to their earlier and greater distractibility of the straight runway. If hippocampal-lesioned Ss had first observed the side alley and entered it, then this type of response should be perseverated. In the present study, all Ss were forced to attend to and enter a side alley (E-alley) that was later placed in the same location (SE-alley) or on the opposite side (OE-alley) of a longer runway. According to the Douglas model (1967), previous experience with the E-alley section should result in more competing exploratory entries to SE-alley and less of such distraction behavior to OE-alley for hippocampectomized Ss than for neocortical-ablated or normal control Ss. lamps $5 \mathrm{ft}$ above the apparatus.

Running time was recorded by a Standard Electric clock connected to a Lafayette photoelectric relay-beam unit. A clock recorded elapsed time between the lifting of the start chamber door and the intersection by $S$ of the beam either in front of the end of the side alley for Phase 1 or in front of the goal chamber drinking tube for Phase 2. The amount of time $S$ spent in front of or in the side alley in Phase 2 was measured by a second clock conncected to a photoelectric relay-beam unit. A beam, $1.5 \mathrm{in}$. from the floor from the main alley wall opposite the side alley, traversed the length of the side alley. An S, either passing by, stopping at, or entering the side alley, transected this beam, and time at or in E-alley was thus recorded.

The type of entry $S$ made was measured by direct observation of $S$ 's behavior through a mirror above the side-alley entrance. Two black lines, 2 in. and 5 in. from the opening in the main alley, were placed on the side alley's floor. A partial head-and-shoulder (HS) entry was noted when $S$ crossed only the 2 -in. line. A complete, whole-body (WhB) entry consisted of a 5-in. entry, i.e., crossing the second line. A mirror above the goal chamber also allowed $\mathrm{E}$ to observe $\mathrm{S}$ drinking.

\section{PROCEDURE}

Pretraining the hippocampus was removed both medially and as far ventrally as could be visually located in order to spare thalamus any injury. Only overlying cortex was removed from the cortical control (CORT) group, care being taken to prevent damage to the hippocampus. After the cessation of all bleeding, gelfoam was inserted in the wound, temporal muscles replaced over the opening in the skull and the scalp closed. Ss received Terramycin drinking solution ad lib for 5 days postoperatively and were allowed a 10- to 14-day recovery period.

\section{APPARATUS}

The complete apparatus consisted of a straight $92 \times 4 \times 5$ in. runway with 15 removable wooden partitions lining each of its sides. Goal and start chamber, each 13 in. long, were set off by guillotine doors. The goal chamber contained a drinking tube $1.5 \mathrm{in}$. above the floor behind another guillotine door. A $36 \times 4 \times 5$ in. side alley could be placed perpendicular to the straight runway at any one of the 15 locations on either side wall when the appropriate wooden partition had been removed. In this study, Ss were presented the side alley (E-alley) either $13 \mathrm{in.}$ on the left or $19 \mathrm{in}$. on the right wall from the start chamber. All interiors were painted flat gray. Constant illumination was provided by four $40-\mathrm{W}$ fluorescent
After the postoperative recovery period, all Ss were maintained on a water-deprivation schedule of $22 \mathrm{~h}$ with $2 \mathrm{~h}$ ad lib for the remainder of the study. Each $\mathrm{S}$ was water-tamed and handled $5 \mathrm{~min}$ per day for 5 days.

Phase 1

Free Exploration

Three daily 4-min free-exploration sessions in the apparatus were given to all Ss. The main alley was blocked off just beyond E-alley, which was located 13 in. from the start chamber on the left side. $S$ was delayed in the start chamber for $1 \mathrm{~min}$, then allowed free exploration for $4 \mathrm{~min}$. Running time to the end of the E-alley for the first run was measured. Number of complete runs from start to end of E-alley or vice versa was also recorded.

\section{Phase 2}

Reinforcement Training Trials

During this phase, the main alley was opened. Half the Ss in each group were able to run down the runway with E-alley in the same position as in Phase 1. E-alley was presented to the other half 19 in. from the start chamber on the right side. Each $S$ received 10 trials/day for 3 days. A training trial consisted of $S$ running down the main runway and drinking the $10 \%$ sucrose solution in the goal chamber. After $S$ had drunk $10 \mathrm{sec}$, guillotine doors came down 

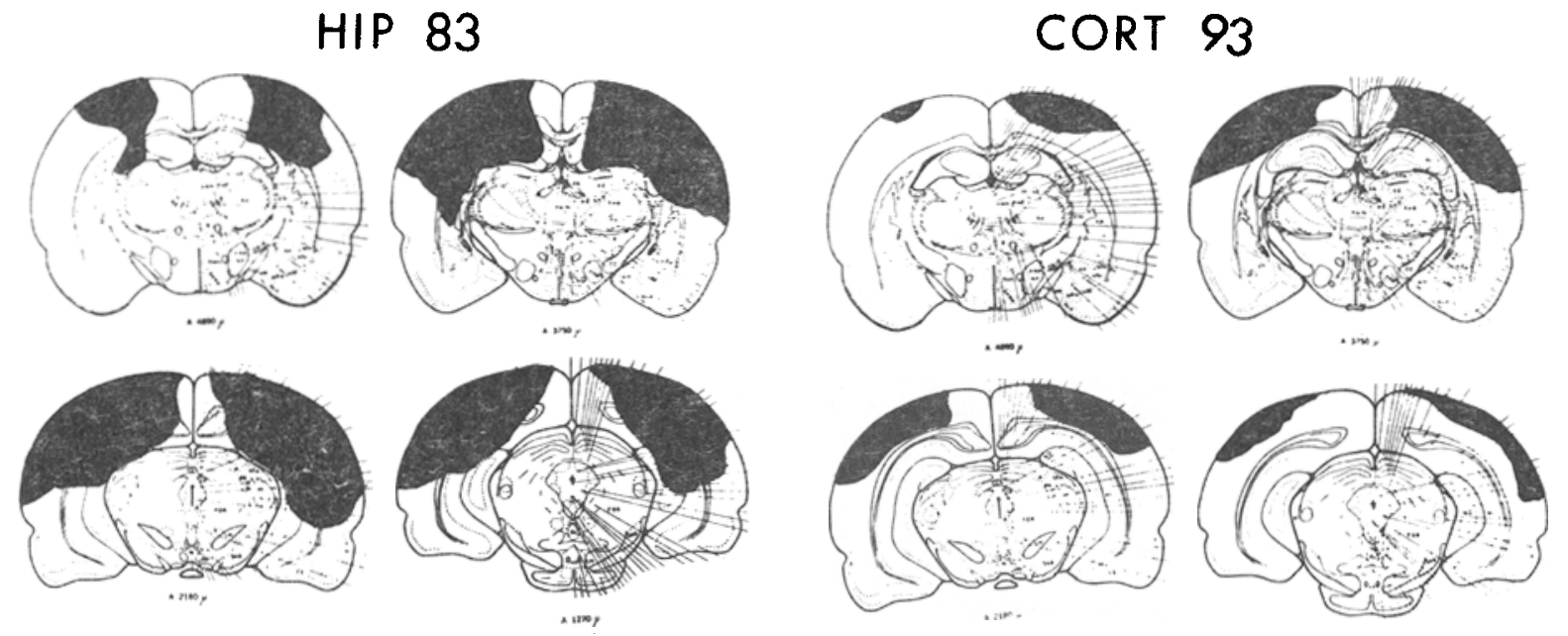

Fig. 1. Example of hippocampal-damaged (HIP) and neocortical-damaged (CORT) Ss. Lesions are superimposed on diagrams from Konig \& Klippel, 1963.

in front of the drinking tube and behind $S$. $S$ was kept in the goal chamber for an additional $20 \mathrm{sec}$, removed and replaced in the start chamber for the next trial.

Running time for each trial from the start chamber to the goal box was measured. Number and type of entries were also recorded for each daily session.

Reinforcement trials were given in order to create conditions similar to the earlier study (Cohen, 1969). Using discrete reinforced trials also allowed for the control of differences in locomotor behavior between the experimental and control groups. In this way, competing exploration behavior was not a function of differences in amount of general activity between groups. The necessity of differentiating between exploration and locomotor activity has been discussed more fully in an earlier study (Cohen \& Stettner, 1968).

\section{Histology}

Three to five days after completion of the last phase, operated Ss were sacrificed with ether and perfused with physiological saline and $10 \%$ formalin. One hippocampectomized $S$ died before histology could be performed. Its data were included in the statistical analyses since during the actual operation hippocampus was visually tracked and removed. Its behavior did not deviate from the rest of this experimental group. The head of each $\mathrm{S}$ was submerged in $10 \%$ formalin for $48 \mathrm{~h}$. Brains were then removed and again submerged in the fixative for another $48 \mathrm{~h}$.

A paraffin embedding technique was utilized in obtaining 15 -micron coronal sections of brain tissue from the anterior to the posterior position of the lesion. Every fourth section was mounted and stained with hematoxylineosin. Histological examination was accomplished with the aid of Koning \& Klippel's atlas (1963) of the rat brain.

\section{RESULTS \\ Histology}

As seen in Fig. 1, HIP Ss showed bilateral lesions of the hippocampus confined primarily to the hippocampal arch and dorsal area. Ventral hippocampi remained almost completely intact. Approximately $30 \%-40 \%$ of the total hippocampus was removed. Overlying neocortex was also ablated. In only one HIP S, No. 86, was there any thalamic damage. Bilateral invasion of the posterior lateral thalamic nucleus and the dorsal nucleus of the lateral geniculate body was seen.

All six CORT Ss showed bilateral lesions of the neocortex overlying the dorsal hippocampus and hippocampal arch. Only two Ss showed slight damage to the hippocampal grey matter. Numbers 94 and 91 had unilateral invasions of the right and left hippocampus, respectively. In each case, more than $95 \%$ of the hippocampus remained intact. All CORT $\mathrm{Ss}$ showed slight bilateral lesions of the overlying fimbria of the hippocampal formation. Behavioral Results

In Phase 1, HIP Ss made more runs than either CORT or NORM Ss. A one-way analysis of variance established the significance of the main effects of brain condition well beyond the .01 level of significance $(F=6.22, \quad d f=2 / 15)$. Individual comparisons (Newman-Keuls test) revealed that HIP $S$ s made significantly more runs $(p<.05)$ than either CORT or NORM Ss, there being no significant differences between the latter two groups. Running times for the first run on each day for each $S$ were converted into reciprocals $(X 1,000)$ in order to satisfy the assumption of normality for parametric analyses. HIP Ss appeared to run faster than other Ss (Table 1). These differences, however, did not reach significance. At least on one measure of activity, HIP Ss were more active than were other Ss.

In Phase 2 , a series of factorial 2 by 3 (Side of E-Alley by Brain Condition) analyses were performed for speed, number of trials explored, number of entries, number of different types of entries, and time spent at, or in and at, the E-alley (Table 2).

Significant main effects for brain condition but not for side or for interaction between the two were seen as follows: number of trials explored, $F=11.11, \mathrm{df}=2 / 12, \mathrm{p}<.01$; number of entries, $F=9.65, p<.01$; number of $\mathrm{HS}$ entries, $F=13.52, p<.01$; number of WhB entries, $F=8.80, p<.01$; time spent at and in E-alley, $F=5.45, p<.05$. No significant effects were seen for running speed or time spent at the E-alley.

Individual comparisons (Newman-Keuls) generally showed that NORM Ss explored more and alone were affected by E-alley location. NORM Ss entered the E-alley on significantly more trials than did either HIP $(p<.01)$ or CORT Ss $(p<.05)$ and made significantly more entries of either HS or WhB variety than either operated group $(p<.01)$. Significantly more trials of exploration and $\mathrm{WhB}$ entries were made by NORM Ss presented the SE-alley than by NORM Ss presented the OE-alley $(\mathrm{p}<.05)$. No significant exploration differences were seen between SE- and Table 1

Mean Runs and Mean Speed (1/Running Time to 0.1 Sec $X 1000$ ) for Phase

\begin{tabular}{lccc}
\hline & Hip & Cort & Norm \\
\hline Runs & 43 & 26 & 22 \\
SD & 13.48 & 8.59 & 6.90 \\
Speed & 78 & 56 & 40 \\
SD & 33.79 & 21.30 & 22.71 \\
\hline
\end{tabular}


Table 2

Mean Speed and Indices (Means) of Exploration in Phase 2

\begin{tabular}{|c|c|c|c|c|c|c|}
\hline & \multicolumn{2}{|c|}{ Hip } & \multicolumn{2}{|c|}{ Cort } & \multicolumn{2}{|c|}{ Norm } \\
\hline & SE-Alley & OE-Alley & SE-Alley & OE-Alley & SE-Alley & OE-Alley \\
\hline $\begin{array}{l}\text { Speed } \\
\text { SD }\end{array}$ & $\begin{array}{c}350 \\
65.45\end{array}$ & $\begin{array}{c}272 \\
68.00\end{array}$ & $\begin{array}{c}276 \\
106.70\end{array}$ & $\begin{array}{c}304 \\
74.00\end{array}$ & $\begin{array}{c}266 \\
118.48\end{array}$ & $\begin{array}{c}232 \\
133.82\end{array}$ \\
\hline $\begin{array}{l}\text { Trials Explored } \\
\text { SD }\end{array}$ & $\begin{array}{l}1.3 \\
1.88\end{array}$ & $\begin{array}{l}1.0 \\
0.82\end{array}$ & $\begin{array}{l}3.7 \\
2.49\end{array}$ & $\begin{array}{l}5.7 \\
2.87\end{array}$ & $\begin{array}{c}16.3 \\
4.11\end{array}$ & $\begin{array}{l}8.0 \\
5.71\end{array}$ \\
\hline $\begin{array}{c}\text { Entries } \\
\text { Total } \\
\text { SD }\end{array}$ & $\begin{array}{l}1.3 \\
1.88\end{array}$ & $\begin{array}{l}1.0 \\
0.82\end{array}$ & $\begin{array}{l}4.7 \\
3.86\end{array}$ & $\begin{array}{l}6.7 \\
1.70\end{array}$ & $\begin{array}{l}20.3 \\
6.60\end{array}$ & $\begin{array}{c}13.3 \\
9.81\end{array}$ \\
\hline $\begin{array}{l}\text { HS } \\
\mathrm{SD}\end{array}$ & $\begin{array}{l}0.0 \\
0.00\end{array}$ & $\begin{array}{l}0.0 \\
0.00\end{array}$ & $\begin{array}{l}2.0 \\
2.83\end{array}$ & $\begin{array}{l}3.3 \\
0.94\end{array}$ & $\begin{array}{l}8.0 \\
2.16\end{array}$ & $\begin{array}{l}7.7 \\
5.79\end{array}$ \\
\hline $\begin{array}{l}\text { WhB } \\
\text { SD }\end{array}$ & $\begin{array}{l}1.3 \\
1.88\end{array}$ & $\begin{array}{l}1.0 \\
0.82\end{array}$ & $\begin{array}{l}2.7 \\
1.25\end{array}$ & $\begin{array}{l}3.3 \\
1.70\end{array}$ & $\begin{array}{l}12.3 \\
4.50\end{array}$ & $\begin{array}{l}5.7 \\
4.11\end{array}$ \\
\hline $\begin{array}{l}\text { Time (Sec) } \\
\text { in at E-Alley } \\
\text { SD }\end{array}$ & $\begin{array}{l}2.6 \\
3.04\end{array}$ & $\begin{array}{l}7.3 \\
4.79\end{array}$ & $\begin{array}{l}24.9 \\
10.31\end{array}$ & $\begin{array}{c}16.0 \\
9.17\end{array}$ & $\begin{array}{l}10.4 \\
5.02\end{array}$ & $\begin{array}{l}17.8 \\
4.45\end{array}$ \\
\hline $\begin{array}{l}\text { at E-Alley } \\
\text { SD }\end{array}$ & $\begin{array}{l}0.4 \\
0.08\end{array}$ & $\begin{array}{l}0.5 \\
0.12\end{array}$ & $\begin{array}{l}1.2 \\
0.85\end{array}$ & $\begin{array}{l}0.5 \\
0.14\end{array}$ & $\begin{array}{l}1.2 \\
0.73\end{array}$ & $\begin{array}{l}2.0 \\
0.95\end{array}$ \\
\hline
\end{tabular}

OE-alley presentation groups by HIP and CORT Ss, respectively. Both time measures of exploration did not show significant differences between groups or between alley presentation subgroups within the same group.

The lack of significant exploration differences between CORT and HIP Ss may have been due to small sample size that obliterated characteristics necessary for difference detection by parametric tests. Mann-Whitney U nonparametric tests, however, showed that CORT Ss spent more trials exploring $(\mathrm{U}=6, \mathrm{p}=.032)$ and made more entries $(U=3, p=.008)$ than did HIP Ss.

Wilcoxon matched-pairs signed-ranks tests failed to establish any significant difference between HS or WhB entry elicitation within NORM or CORT Ss. Only three HIP Ss made any entries, all being WhB entries. Not enough HIP Ss made entries to carry out statistical analyses.

An analysis of exploratory activity of the first trial in Phase 2, before $S$ had acquired an expectancy of reinforcement in the goal chamber, was carried out. One HIP S (OE-alley subgroup), one CORT S (SE-alley subgroup), and five NORM Ss (two in the SE and three in the OE-alley subgroups) entered the E-alley on this trial. Fisher exact probability tests showed that significantly more NORM Ss explored the E-alley than either other group $(p=.05)$. blocking wall in Phase 1. One HIP S managed to push aside the blocking partition and continue down the straight alley until caught by $E$.

This study also suggests that other cerebral structures besides hippocampus may serve stimulus-gating functions. Only NORM Ss showed an E-alley position effect, whereas CORT and HIP Ss did not. REFERENCES

COHEN, J. S. Effects of hippocampal lesions and exploratory activity in the albino rat. Unpublished doctoral dissertation, Wayne State University, 1969.

COHEN, J. S., \& STETTNER, L. J. Effects of deprivation level on exploratory behavior in the albino rat. Joumal of Comparative \& Physiological Psychology, 1968, 66, 514-517. DOUGLAS, R. J. The hippocampus and behavior. Psychological Bulletin, 1967, 67, 416-442.

HOSTETTER, G., \& THOMAS, G. J. Evaluation of enhanced thigmotaxis as a condition of impaired maze learning by rats with hippocampal lesions. Journal of Comparative \& Physiological Psychology, 1967, 63, 105-110.

Thus, exploratory differences cannot be due solely to any drive level changes caused by hippocampectomy.

\section{CONCLUSIONS AND DISCUSSION}

According to the stimulus-gating model proposed by Douglas (1967), perseverative responses in hippocampectomized $S$ occur in the presence of stimuli to which $S$ previously responded. The present study shows, however, that previous experience with a side arm or E-alley did not lead to more perseverative turning behavior in hippocampal-damaged than in control Ss. HIP Ss explored the E-alley less than NORM or CORT Ss. These results do not invalidate Douglas's model, but raise the question concerning the type of stimuli that will most easily distract hippocampal-damaged Ss. In this and the previous study (Cohen, 1969), a straight alley, or stimuli permitting a forward-moving response, might be more distracting to hippocampal-damaged Ss than to control Ss. It should be noted, however, that previous investigators have failed to find more distractibility to novel light and floor-texture stimuli along a straight runway in hippocampectomized Ss (Wickelgren \& Isaacson, 1963; Raphelson et al, 1965). These earlier findings suggest that perseverative behavior in hippocampal-damaged Ss may be due to a response inhibition deficit according to Kimble (1968). In the present work, there was a tendency for HIP Ss to run into the
KIMBLE, D. P. The effects of bilateral hippocampal lesions in rats. Journal of Comparative \& Physiological Psychology, 1963, 56, 273-283.

KIMBLE, D. P. Hippocampus and internal inhibition. Psychological Bulletin, 1968, 70, 285-295.

KONIG, J., \& KLIPPEL, R. A. The rat brain, a stereotaxic atlas. Baltimore: William \& Wilkins, 1963.

LEATON, R. N. Exploratory behavior in rats with hippocampal lesions. Journal of Comparative \& Physiological Psychology, 1965, 59, 325-330.

RAPHELSON, A. C., ISAACSON, R. L., \& DOUGLAS, R. J. The effect of distracting stimuli on the runway performance of limbic damaged rats. Psychonomic Science, 1965, 3, 483-484.

SENGSTAKE, C. B. Habituation and activity under various drive conditions. Journal of Comparative \& Physiological Psychology, 1968, 65, 504-506.

WICKELGREN, W. O., \& ISAACSON, R. L. Effect of introduction of an irrelevant stimulus upon runway performance of the hippocampectomized rat. Nature, 1963, 200, 48-50.

1. The present study was supported by research funds from the Department of Psychology, University of Windsor. The authors wish to thank Dr. David Asdourian for his generous advice and for the use of the physiological psychology facilities at Wayne State University. We also wish to thank Dr. J. Habowsky for his technical advice and for the use of histological facilities of the Department of Biology, University of Windsor.

2. Now at Occidental College, Los Angeles, Calif. 90041 . patterns of rats with large hippocampal lesions 